This article is licensed under the Creative Commons Attribution-NonCommercial 4.0 International License (CC BY-NC) (http://www.karger.com/Services/OpenAccessLicense). Usage and distribution for commercial purposes requires written permission.

\title{
Hepatitis E-Induced Acute Myocarditis in an Elderly Woman
}

\author{
Pratim Sengupta $^{a} \quad$ Sumanta Biswas ${ }^{b} \quad$ Tapas Roy $^{c}$ \\ ${ }^{a}$ Chief Nephrologist and Director of Renal Transplant Programme, Department of \\ Nephrology, ILS Hospital, Kolkata, India; ${ }^{b}$ Clinical Research Associate, Department of \\ Nephrology, ILS Hospital, Kolkata, India; 'Senior Registrar, Department of Nephrology, \\ ILS Hospital, Kolkata, India
}

\section{Keywords}

Hepatitis E - Myocarditis · Dilated cardiomyopathy · Elderly woman

\begin{abstract}
Hepatitis E is a common, mainly water-borne hepatotropic virus prevalent mainly in Southeast Asia, Africa, the Middle East, and Central America. In the eastern part of India epidemics of acute hepatitis $E$ are well reported. Hepatitis E commonly presents as self-limiting acute viral hepatitis among young adults, except for some critical clinical complications during pregnancy. In epidemiological research, subclinical acute hepatitis E infection is also reported from different parts of the world, including developed nations such as the USA (predominantly in the population aged $>60$ years). Though primarily hepatotropic, in the literature there are reports of rare extrahepatic manifestation of acute hepatitis E. Here we present an elderly lady with acute hepatitis $\mathrm{E}$ who primarily presented with acute myocarditis.
\end{abstract}




\section{Case Reports in Gastroenterology}

Case Rep Gastroenterol 2019;13:342-349

DOI: $10.1159 / 000501998$

(c) 2019 The Author(s). Published by S. Karger AG, Basel www.karger.com/crg

Sengupta et al.: Hepatitis E-Induced Acute Myocarditis in an Elderly Woman

\section{Introduction}

India is an endemic zone of hepatitis E virus (HEV), which is associated with both sporadic and epidemic infections. West Bengal in India is an endemic zone of HEV and there have been several outbreaks of HEV. In an epidemiological study done in West Bengal, the presence of anti-HEV IgG antibody was found in $41.8 \%$ of patients with acute viral hepatitis and in $23 \%$ of healthy individuals, indicating a high prevalence of HEV [1]. Hepatitis E is a self-limiting disease and most people with hepatitis E recover completely, except for antenatal HEV infection which leads to significant maternal mortality, especially in the third trimester $115-25 \%$ of cases) [2]. Apart from hepatic manifestation, hepatitis E causes florid extrahepatic manifestations including acute pancreatitis, Guillain-Barré syndrome, neuralgic amyotrophy, haemolytic anaemia, thrombocytopenia, glomerulonephritis, and mixed cryoglobulinaemia. Viral infection is an important cause of acute myocarditis, and the spectrum of viruses known to cause myocarditis has changed in the past two decades. Myocarditis occurs due to a self-directed immune response between host-pathogen interaction that affects mainly younger adults. Acute myocarditis is uncommon in hepatitis $\mathrm{E}$ infection and has been reported in young adults in the literature. Despite several reported outbreaks of HEV in West Bengal, up to date, there is no reported case of HEV-induced myocarditis especially in the elderly. To the best of our knowledge, this is the first case of hepatitis E-induced acute myocarditis, observed in an elderly woman from West Bengal, India.

\section{Case Report}

A 79-year-old housewife presented to our hospital with exertional dyspnoea, gradually increasing shortness of breath, chest pain, palpitation, and decreased urine output over the last 4-5 days, with severe exacerbation of dyspnoea and watery diarrhoea for the last 2 days. She denied any history of diabetes, hypertension, any pre-existing liver disease, abdominal discomfort, or passage of blood or mucus in stool. She was known to have intermittent shortness of breath especially in the winter season, but she admitted that she was very irregular in taking inhaled bronchodilators prescribed by her physician. She had never required hospital admission for exacerbation of chronic obstructive pulmonary disease. This time there was no history of fever, cough with expectoration, jaundice, pruritus, melena, haemoptysis, or altered sensorium. On inquiry she admitted that for the last 10-15 days she had not been feeling well, feeling feverish, having malaise, being fatigued and having lost her usual appetite. She did not have any skin rash or arthralgia. Clinical observation at the emergency room revealed that she was orthopneic, conscious, and oriented. She was anaemic and there was mild icterus, but she was not cyanotic, and no clubbing was noticed. There was mild pitting oedema at her feet. On admission her blood pressure was $120 / 70 \mathrm{~mm} \mathrm{Hg}$, heart rate was $104 / \mathrm{min}$, respiratory rate was $24 / \mathrm{min}$, temperature was $98^{\circ} \mathrm{F}$, oxygen saturation breathing room air was $91 \%$, and capillary blood glucose was $121 \mathrm{mg} / \mathrm{dL}$. Her abdomen was soft with mild tenderness at the right hypochondrium. There were no organomegaly nor palpable mass or lymph nodes. There was no focal neurodeficit. Cardiac auscultation revealed S3 gallop. The respiratory system revealed bi-basal crepitations in both lung fields with bilateral diffuse rhonchi. She was advised immediate admission from the emergency room. 


\section{Case Reports in Gastroenterology} \begin{tabular}{l|l}
\hline Case Rep Gastroenterol 2019;13:342-349 \\
\hline DOI: 10.1159/000501998 & $\begin{array}{l}\text { @ 2019 The Author(s). Published by S. Karger AG, Basel } \\
\text { www.karger.com/crg }\end{array}$
\end{tabular}

Sengupta et al.: Hepatitis E-Induced Acute Myocarditis in an Elderly Woman

After admission, her initial laboratory investigation revealed a haemoglobin of $9.4 \mathrm{~g} / \mathrm{dL}$, a total leucocyte count of 13,000 cells/ $\mu \mathrm{L}$, a serum sodium of $133 \mathrm{mmol} / \mathrm{L}$, and a serum potassium of $4.2 \mathrm{mmol} / \mathrm{L}$. Serum procalcitonin was $0.61 \mathrm{ng} / \mathrm{mL}$ and C-reactive protein was $30 \mathrm{mg} / \mathrm{L}$. Urine for culture and sensitivity was positive for the growth of Escherichia coli with 1 lakh CFU/mL. Her total bilirubin was $4.2 \mathrm{mg} / \mathrm{dL}$ with a direct fraction of $2.9 \mathrm{mg} / \mathrm{dL}$ and an indirect fraction of $1.3 \mathrm{mg} / \mathrm{dL}$. Her liver enzymes were severely elevated; aspartate transaminase 2,451 U/L, alanine transaminase $904 \mathrm{U} / \mathrm{L}$, and gamma-glutamyltransferase $116.5 \mathrm{U} / \mathrm{L}$, suggestive of acute liver injury. Her coagulation profile was deranged with an international normalized ratio of 2.37 and an altered albumin globulin ratio. Serum amylase was 1,047 U/L and lipase was 38.1 U/L. Portal vein Doppler showed increased velocity in the splenoportal vein $(17.2 \mathrm{~cm} / \mathrm{s})$. There was no thrombus in the inferior vena cava or the hepatic vein. Her direct Coombs test was negative. Her blood urea was $66 \mathrm{mg} / \mathrm{dL}$, and serum creatinine was $2.1 \mathrm{mg} / \mathrm{dL}$ with normal electrolytes. To understand the exact aetiology of hepatic injury, a viral screen was sent. IgM anti-HEV came strongly positive with a very high titre. Other viral screens such as hepatitis A, hepatitis B, hepatitis C, HIV, and dengue all came negative, and IgM for Leptospira was also negative. Her peripheral blood smear for malaria parasite and rapid malarial antigen tests were negative. Her routine urine showed 1+ protein and plenty of pus cells without any cast red blood cells. High-flow oxygen, diuretic, and bronchodilators along with supportive care for acute hepatitis-like vitamin K, ursodeoxycholic acid, and multivitamin were started with close monitoring of liver function. In view of plenty of pus cells in urine, one broad-spectrum antibiotic was started which further escalated to meropenem based on culture sensitivity report, but there was no improvement in her respiratory distress. She was restless and dyspnoeic. Repeat arterial blood gas analysis revealed type 1 respiratory failure with hypoxemia, and ECG showed sinus tachycardia, elevation of the PR segment, and dynamic ST-T changes. Chest X-ray was suggestive of pulmonary congestion. Urgent 2D echocardiography revealed generalized and global hypokinesia of myocardium; on diffusion image the myocardium seemed to be oedematous. All the four chambers of the heart were dilated, LV and RV size were enlarged, and the ejection fraction was 25\%, suggestive of dilated cardiomyopathy (Fig. 1, 2, 3). NT pro-BNP was markedly high $(>35,000 \mathrm{pg} / \mathrm{mL})$ and creatinine kinase-MB fraction levels were increased $(239.1 \mathrm{mg} / \mathrm{dL}, 17.42 \%$ of total $\mathrm{CK})$. This was suggestive of myocarditis with acutely decompensated heart failure, and a low-dose cardioselective B1 adrenergic agent was started. Intravenous furosemide was added to optimize intravascular volume. Nitrate was given. Initially ivabradine was given, then a beta-blocker was added after spasm had subsided. She required non-invasive ventilation support using continuous positive airway pressure at $10 \mathrm{~cm} \mathrm{H}_{2} \mathrm{O}$ to maintain adequate tissue oxygenation. Cardiology consultation was sought for and a coronary angiogram was done to rule out any coronary artery disease. No significant abnormalities were noted in the coronary angiogram.

Over a period of 2 days, the patient gradually improved and was weaned off non-invasive ventilation support. Her biochemical parameters indicated an improvement of liver function. The antibiotic was stepped down gradually with improvement in renal function. With adequate nutritional therapy, diuretics, and other conservative management, she started showing positive improvements in her clinical parameters. Serum creatinine came down to $1.9 \mathrm{mg} / \mathrm{dL}$, she started passing adequate urine of around 2 L/day, maintained an oxygen saturation breathing room air of $98 \%$, and there was no dyspnoea. All her liver enzymes (aspartate transaminase $119 \mathrm{U} / \mathrm{L}$, alanine transaminase $307 \mathrm{U} / \mathrm{L}$, gamma-glutamyltransferase $79 \mathrm{U} / \mathrm{L}$ ) settled 


\section{Case Reports in Gastroenterology}

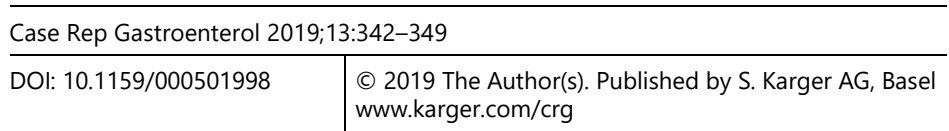
www.karger.com/crg

Sengupta et al.: Hepatitis E-Induced Acute Myocarditis in an Elderly Woman

down in 7 days. Persistently her urine output improved and tachycardia subsided. A repeat 2D echocardiogram after 14 days showed improvement in cardiac contractility with an ejection fraction of 50\% (Fig. 2). The blood investigation results on admission and at discharge are shown in Table 1. As she rapidly improved over the next few days and subsequent cardiac evaluation was normal by day 14 , she was screed only by echocardiography. She was discharged on day 16 of the hospital stay.

\section{Discussion}

Acute myocarditis, or inflammation of the heart muscle, is a serious clinical complication mainly arising from infective (mainly viral/parasitic/bacterial) and non-infective aetiology (granulomatous inflammatory disease, polymyositis, dermatomyositis, toxin exposure such as alcohol, heavy metal poisoning, nutrient deficiency). Acute myocarditis often presents with acute life-threatening decompensated heart failure and leads to permanent damage of the myocardium, leading to dilated cardiomyopathy. Systemic viral infection and immunological response targeting the myocardium secondary to viremia is an imperative reason for postviraemic myocarditis. The picornavirus family of RNA viruses - principally enterovirus, Coxsackievirus, ECHO virus influenza, and poliovirus - is mainly implicated as a causative agent for postviral myocarditis. In the literature, numerous other viral infections have been reported as reasons for myocarditis, including parvoviruses, adenovirus, H1N1 flu infection, Epstein-Barr virus infection, rubella (German measles), varicella (chickenpox), mumps, measles, yellow fever, dengue, polio, rabies, hepatitis A and C, HIV, and Zika infection, and parvovirus B19 [3-7]. Viral myocarditis usually progresses on two stages although the exact pathophysiology mechanism in humans is still not completely understood. First, the viral infection generates direct damages to the myocardium (virus-mediated lysis of myocardial cells), and then host immune responses produce indirect lesions of the cardiac muscle by killing virusinfected (antiviral immunity) and -uninfected (autoimmunity) cardiomyocytes; some cases progress to dilated cardiomyopathy, and some may result in heart failure or sudden death [810]. Myocarditis is one of the rarest extrahepatic complications of hepatitis E infection. Up to date, hepatitis E-mediated intense myocarditis has been accounted for in three peer-reviewed journals, of which two were from the Indian peninsula and other from the western hemisphere, and all patients were young adults aged $<40$ years. The pathophysiology of postinfective myocarditis being immunogenic and depending on the host immune response, mostly young adults are affected. However, the non-infective aetiology of myocarditis has no age bar. Postinfective myocarditis in the elderly is rare. Viral myocarditis presents with various symptoms, ranging from negligibly symptomatic cases to fatal arrhythmia and cardiogenic shock, and may create chronic myocarditis and enlarged cardiomyopathy in a few patients $[11,12]$. A combination of clinical features, laboratory findings, and imaging studies is the mainstay to diagnose myocarditis. The Dallas criteria [13], which rely on traditional histological stains, remain the standard for diagnosis of myocarditis. Regardless of the endomyocardial biopsy yield being just 10-20\%, endomyocardial biopsy findings remain the standard of care for diagnosing myocarditis [14]. Cardiac MRI might be helpful for diagnosing myocarditis by documenting muscle oedema, hyperaemia, or fibrosis [15]. The clinical diagnosis of myocarditis was established based on the clinical setting and finding of specific changes in ECG, global 
hypokinesia with dilatation of all four chambers of the heart along with reduced ejection fraction in echocardiography, elevated cardiac enzymes, and high NT pro-BNP. Normal coronary angiography ruled out ischemic cardiomyopathy. Endomyocardial biopsy was not performed as the patient's relatives did not give consent, understanding the inherent risk of the procedure at this age. HEV-induced acute myocarditis was the only apparent cause for this acutely decompensated heart failure. HEV being a self-remitting disease, the patient started to improve clinically over the next week. With the gradual resolution of liver enzymes and the disappearance of viremia, cardiac function also improved. Overall, clinical cardiac status and echo parameters significantly improved over the next 2 weeks. On the fourteenth day after admission, the patient's ejection fraction had improved to $50 \%$, there was no dyspnoea, and she required no oxygen.

\section{Conclusion}

The concomitant acute viral hepatitis $\mathrm{E}$ and acute myocarditis in this case and the subsequent resolution of cardiac symptoms with a resolution of acute hepatitis indicated an aetiological link between hepatitis and myocarditis. We feel that it is pertinent to report that benign self-limiting acute hepatitis $\mathrm{E}$ can sometimes be complicated by life-threatening acute myocarditis leading to decompensated heart failure. In spite of the fact that there were repeated outbreaks of viral hepatitis E in West Bengal, there had to date been no reported case of HEVinduced acute myocarditis. To our knowledge, this is so far the first ever reported case from West Bengal, and we feel that hepatitis E should also be kept in mind as a possible viral aetiology of acute myocarditis, irrespective of age.

\section{Statement of Ethics}

This article does not contain any studies with human participants or animals performed by any of the authors. Informed consent was obtained from the participant included in the study.

\section{Disclosure Statement}

The authors declare that no conflict of interest exists.

\section{References}

1 Bazerbachi F, Haffar S, Garg SK, Lake JR. Extra-hepatic manifestations associated with hepatitis E virus infection: a comprehensive review of the literature. Gastroenterol Rep (Oxf). 2016 Feb;4(1):1-15.

2 Chaudhry SA, Verma N, Koren G. Hepatitis E infection during pregnancy. Can Fam Physician. 2015 Jul;61(7): 607-8.

3 Fairweather D, Stafford KA, Sung YK. Update on coxsackievirus B3 myocarditis. Curr Opin Rheumatol. 2012 Jul;24(4):401-7. 


\section{Case Reports in Gastroenterology}

\begin{tabular}{l|l}
\hline Case Rep Gastroenterol 2019;13:342-349 \\
\hline DOI: 10.1159/000501998 & $\begin{array}{l}\text { ○ 2019 The Author(s). Published by S. Karger AG, Basel } \\
\text { www.karger.com/crg }\end{array}$ \\
\hline
\end{tabular}

Sengupta et al.: Hepatitis E-Induced Acute Myocarditis in an Elderly Woman

4 Spartalis M, Tzatzaki E, Spartalis E, Damaskos C, Mavrogeni S, Voudris V. Parvovirus B19 myocarditis of fulminant evolution. Cardiol Res. 2017 Aug;8(4):172-5.

5 Lobo ML, Taguchi Â, Gaspar HA, Ferranti JF, de Carvalho WB, Delgado AF. Fulminant myocarditis associated with the H1N1 influenza virus: case report and literature review. Rev Bras Ter Intensiva. 2014 Jul-Sep; 26(3):321-6.

6 Ntusi NA. HIV and myocarditis. Curr Opin HIV AIDS. 2017 Nov;12(6):561-5.

7 Minhas AM, Nayab A, Iyer S, Narmeen M, Fatima K, Khan MS, et al. Association of Zika virus with myocarditis, heart failure, and arrhythmias: a literature review. Cureus. 2017 Jun 27;9(6):e1399.

8 Fung G, Luo H, Qiu Y, Yang D, McManus B. Myocarditis. Circ Res. 2016 Feb;118(3):496-514.

9 Kindermann I, Barth C, Mahfoud F, Ukena C, Lenski M, Yilmaz A, et al. Update on myocarditis. J Am Coll Cardiol. 2012 Feb;59(9):779-92.

10 Nikolaou M, Lazaros G, Karavidas A, Hatzianastasiou S, Miliopoulos D, Adamopoulos S. Recurrent viral myocarditis: the emerging link toward dilated cardiomyopathy. Hellenic J Cardiol. 2018 Jan-Feb;59(1):60-3.

11 Schultz JC, Hilliard AA, Cooper LT Jr, Rihal CS. Diagnosis and treatment of viral myocarditis. Mayo Clin Proc. 2009 Nov;84(11):1001-9.

12 Sun NC, Smith VM. Hepatitis associated with myocarditis. Unusual manifestation of infection with Coxsackie virus group B, type 3. N Engl J Med. 1966 Jan;274(4):190-3.

13 Aretz HT, Billingham ME, Edwards WD, Factor SM, Fallon JT, Fenoglio JJ Jr, et al. Myocarditis. A histopathologic definition and classification. Am J Cardiovasc Pathol. 1987 Jan;1(1):3-14.

14 Premkumar M, Rangegowda D, Vashishtha C, Bhatia V, Khumuckham JS, Kumar B. Acute viral hepatitis E is associated with the development of myocarditis. Case Reports Hepatol. 2015;2015:458056.

15 Friedrich MG, Sechtem U, Schulz-Menger J, Holmvang G, Alakija P, Cooper LT, et al.; International Consensus Group on Cardiovascular Magnetic Resonance in Myocarditis. Cardiovascular magnetic resonance in myocarditis: A JACC White Paper. J Am Coll Cardiol. 2009 Apr;53(17):1475-87.

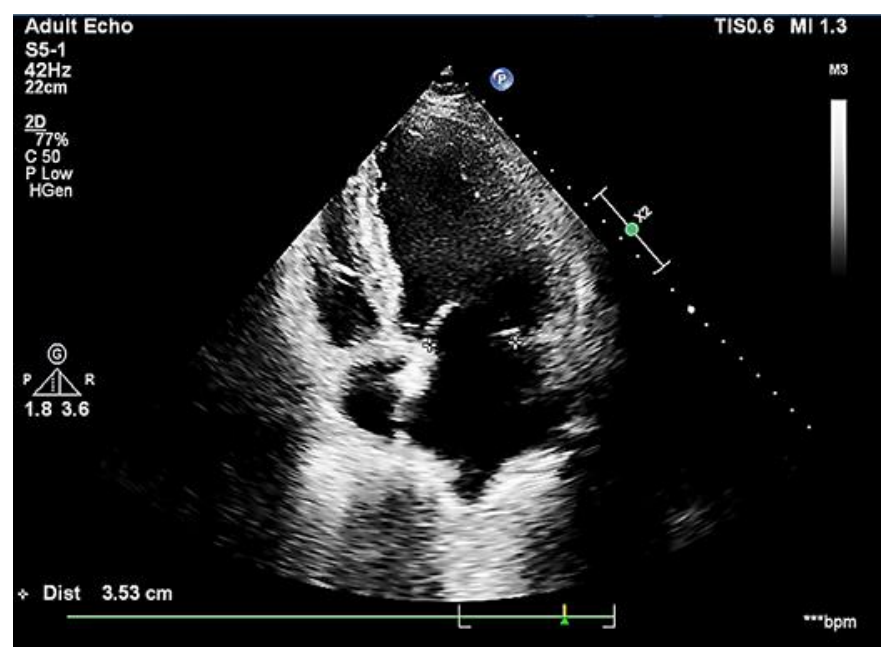

Fig. 1. Echocardiography showing dilatation of all four chambers with poor contractility. 


\section{Case Reports in Gastroenterology}

www.karger.com/crg

Sengupta et al.: Hepatitis E-Induced Acute Myocarditis in an Elderly Woman

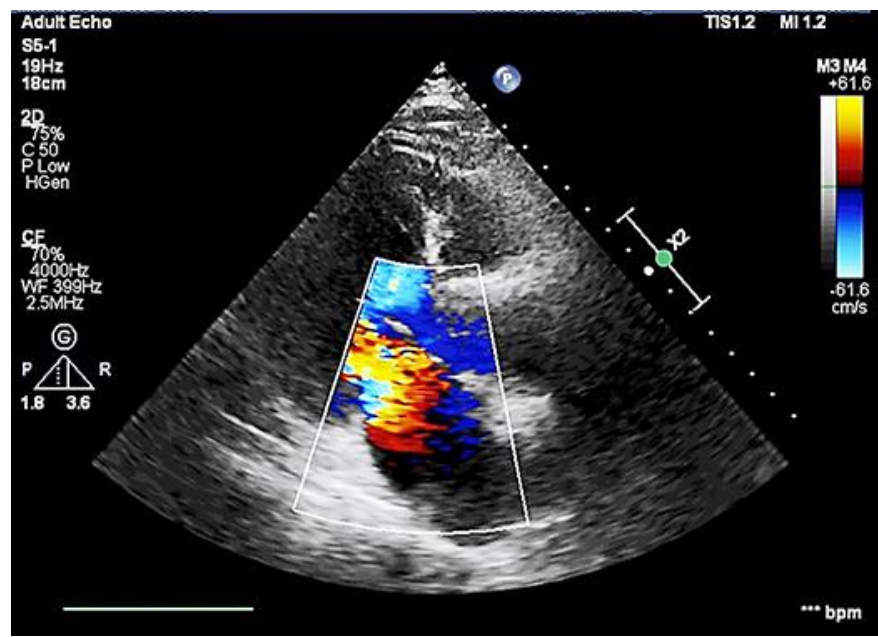

Fig. 2. Colour Doppler showing reduced ejection faction with regurgitation.

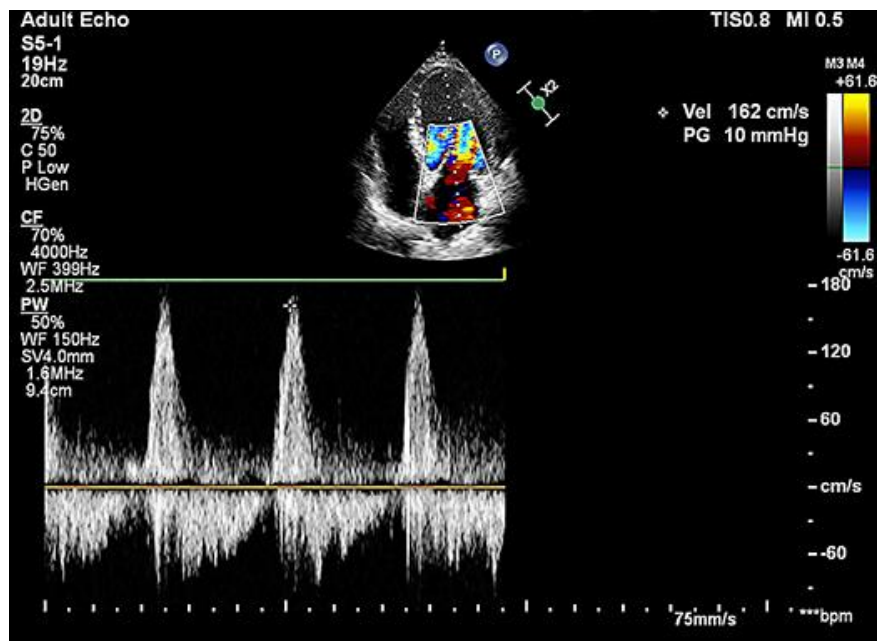

Fig. 3. Diffusion-weighted image showing an oedematous myocardial wall. 


\section{Case Reports in Gastroenterology}

\begin{tabular}{l|l}
\hline Case Rep Gastroenterol 2019;13:342-349 \\
\hline DOI: 10.1159/000501998 & $\begin{array}{l}\text { @ } 2019 \text { The Author(s). Published by S. Karger AG, Basel } \\
\text { www.karger.com/crg }\end{array}$ \\
\hline
\end{tabular}

Sengupta et al.: Hepatitis E-Induced Acute Myocarditis in an Elderly Woman

Table 1. Blood investigations during the hospital stay

\begin{tabular}{lll}
\hline Parameters & On admission & On discharge \\
\hline Haemoglobin & $9.4 \mathrm{~g} / \mathrm{dL}$ & $10.3 \mathrm{~g} / \mathrm{dL}$ \\
Total leucocyte count & $13,000 \mathrm{cells} / \mu \mathrm{L}$ & $7,600 \mathrm{cells} / \mu \mathrm{L}$ \\
Serum sodium & $133 \mathrm{mmol} / \mathrm{L}$ & $135 \mathrm{mmol} / \mathrm{L}$ \\
Serum potassium & $4.2 \mathrm{mmol} / \mathrm{L}$ & $3.9 \mathrm{mmol} / \mathrm{L}$ \\
Serum procalcitonin & $0.61 \mathrm{ng} / \mathrm{mL}$ & $0.30 \mathrm{ng} / \mathrm{mL}$ \\
C-reactive protein & $30 \mathrm{mg} / \mathrm{L}$ & $10 \mathrm{mg} / \mathrm{L}$ \\
Total bilirubin & $4.2 \mathrm{mg} / \mathrm{dL}$ & $1.2 \mathrm{mg} / \mathrm{dL}$ \\
Direct bilirubin & $2.9 \mathrm{mg} / \mathrm{dL}$ & $0.9 \mathrm{mg} / \mathrm{dL}$ \\
Indirect bilirubin & $1.3 \mathrm{mg} / \mathrm{dL}$ & $0.3 \mathrm{mg} / \mathrm{dL}$ \\
Aspartate transaminase & $2,451 \mathrm{U} / \mathrm{L}$ & $53 \mathrm{U} / \mathrm{L}$ \\
Alanine transaminase & $904 \mathrm{U} / \mathrm{L}$ & $147 \mathrm{U} / \mathrm{L}$ \\
Gamma-glutamyltransferase & $116.5 \mathrm{U} / \mathrm{L}$ & $56.2 \mathrm{U} / \mathrm{L}$ \\
International normalized ratio & 2.37 & 1.17 \\
Serum albumin & $4.2 \mathrm{~g} / \mathrm{dL}$ & $3.2 \mathrm{~g} / \mathrm{dL}$ \\
Serum globulin & $1.5 \mathrm{~g} / \mathrm{dL}$ & $2.4 \mathrm{~g} / \mathrm{dL}$ \\
Serum amylase & $1,047 \mathrm{U} / \mathrm{L}$ & $62 \mathrm{U} / \mathrm{L}$ \\
Serum lipase & $38.1 \mathrm{U} / \mathrm{L}$ & $28 \mathrm{U} / \mathrm{L}$ \\
Serum urea & $66 \mathrm{mg} / \mathrm{dL}$ & $59.7 \mathrm{mg} / \mathrm{dL}$ \\
Serum creatinine & $2.1 \mathrm{mg} / \mathrm{dL}$ & $1.9 \mathrm{mg} / \mathrm{dL}$ \\
Serum sodium & $134 \mathrm{mmol} / \mathrm{L}$ & $133 \mathrm{mmol} / \mathrm{L}$ \\
Serum potassium & $3.2 \mathrm{mmol} / \mathrm{L}$ & $4 \mathrm{mmol} / \mathrm{L}$ \\
NT pro-BNP & $>35,000 \mathrm{pg} / \mathrm{mL}$ & - \\
CPK & $1,371.9 \mathrm{U} / \mathrm{L}$ & $29.4 \mathrm{U} / \mathrm{L}$ \\
CPK-MB & $239.1 \mathrm{U} / \mathrm{L}$ & $9.3 \mathrm{U} / \mathrm{L}$ \\
\hline
\end{tabular}

